\title{
Reconstruction of the Macromolecular Antitumor Antibiotic SN-07 from SN-07 Chromophore and DNA
}

\author{
Ken-ichi Kimura, Hidetoshi TaKahashi, Shōji NaKayama, \\ Nobuo Miyata and Gosei Kawanishi \\ Research Institute of Life Science, Snow Brand Milk Products Co., Ltd., \\ Ishibashi-machi, Shimotsuga-gun, Tochigi 329-05, Japan
}

Received December 23, 1988

\begin{abstract}
To characterize the novel macromolecular antitumor antibiotic SN-07 and the role of DNA in SN-07, we reconstructed $\mathrm{SN}-07$ in vitro from $\mathrm{SN}-07$ chromophore and calf thymus DNA. Reconstructed SN-07 was identical with the native $\mathrm{SN}-07$ in the ultraviolet absorption spectrum, nuclease-resistance characteristics, and biological activities (antibacterial activity and cytotoxicity). The DNA moiety promoted the cytotoxic activity of SN-07 chromophore against $\mathrm{KB}$ and HeLa cells, but suppressed the activity against some bacteria and $L 1210$ cells. DNA containing guanine suppressed the activity more strongly than DNA not containing guanine against some bacteria and L1210 cells. The antibacterial activity of $\mathrm{SN}_{-107}$ chromophore was affected by dosage only when DNA was supplied, but not RNA or BSA. Thus the DNA composition of the SN-07 chromophore-DNA complex affected the activity of $\mathrm{SN}-07$ chromophore and guanine had an important role of the binding of $\mathrm{SN}-07$ chromophore to DNA.
\end{abstract}

SN-07, a novel macromolecular antitumor antibiotic produced by Actinomadura roseoviolacea var. miuraensis nov. var. has an average molecular weight of 22,000 and consists of a chromophore and DNA. ${ }^{1)}$ It is active against several experimental tumors including P388 leukemia, L1210 leukemia, and B16 melanoma, and some bacteria. ${ }^{1,2)}$ We tried to isolate the SN-07 chromophore (I) from SN-07 by boiling or nuclease digestion, but (I) was very labile, and (I) was not released from DNA completely.

Recently, we succeeded in isolating an anthracycline antibiotic from the mycelial cake of the microorganism and identified it with (I) by ${ }^{1} \mathrm{H}$ NMR, HPLC, FD-MS, and TLC analyses. ${ }^{3)}$ The above microorganism also produced some kinds of anthracycline antibiotics such as carminomycins II, III, ${ }^{4}$ 7) and SN$706,{ }^{8)}$ but SN-07 ((I)-DNA complex) was only isolated from the supernatant of the culture. So we were interested in the structure of (I) and the binding mode of (I) to DNA. We elucidated the structure of (I), but the result was that it was identical with barminomycin
I. ${ }^{9,10)}$ It was an anthracycline antibiotic, but was atypical of this group because (I) contained an eight-membered ring with the carbinolamine structure. The carbinolamine structure was altered to aldehyde, imine, and/or enamine structures in some conditions. ${ }^{11}$ The carbinolamine and imine functions were similar to those of pyrrolo $(1,4)$ benzodiazepine antitumor antibiotics that bound to the 2amino group of guanine covalently. ${ }^{12 \sim 15)}$ The structural similarity suggested to us that (I) might be bound to DNA covalently.

In this paper, we report the reconstruction of SN-07 (designated Reconstructed SN-07 (II)) from (I) and calf thymus DNA. The characteristics of (II) were identical with the native SN-07. It was also possible to produce various (II) derivatives depending on the DNA composition, and we examined the preliminary biological activities of these. The DNA composition of various (II) derivatives affected the activity of (I). Thus we propose a model for the SN-07 structure and the binding mode of (I) to DNA, which is that (I) binds to guanine covalently. 


\section{Materials and Methods}

SN-07 and SN-07 chromophore. SN-07 was purified as described previously. ${ }^{11} \mathrm{SN}-07$ was defined by the absorbance ratio of (I) and DNA $\left(A_{505} / A_{260}=0.08\right)$. The average molecular ratio of (I) and DNA was about $1: 16$ calculated by the molecular weight ( $\mathrm{SN}-07$ chromophore $=657$, DNA 1 base $=325$ ). (I) was also purified as described previously. ${ }^{3)}$ Carminomycin III was obtained by sodium cyanoborohydride reduction of (I). ${ }^{\text {9) }}$ Solutions of $\mathrm{SN}-07$ and (I) were usually prepared from water and methanol stock solutions $(1 \mathrm{mg} / \mathrm{ml})$ stored at $-20^{\circ} \mathrm{C}$, respectively. The concentration of each stock solution was measured by the weight. The structures of (I) (carbinolamine type) and anthramycin ${ }^{16,17)}$ are shown in Fig. 1.

Reconstruction of $S N-07$. Calf thymus DNA (16.8 O.D. $260 / \mathrm{mg}$, average molecular weight $=1.63 \times 10^{7}$ ) and synthetic polydeoxyribonucleotides were purchased from Pharmacia Fine Chemicals. (I) and DNA were mixed in TE buffer (10 mM Tris- $\mathrm{HCl}$ pH 8.0, $1 \mathrm{~mm}$ EDTA) or in distilled water according to the average ratio of $\mathrm{SN}-07$. The final methanol concentration was less than $10 \%$. (I)DNA mixture was left at room temperature over 2 days and was treated with $\mathrm{CHCl}_{3}$ to remove free (I). The water layer of (II) was lyophilized. The content of (I) in (II) was measured spectrophotometrically $\left(A_{505}=0.1\right.$ is equivalent to $10 \mu \mathrm{g}$ of (I)). (II) and the various (II) derivatives were used for the following experiments.

UV spectrum. The UV absorption spectrum of (I) upon reaction with DNA was measured by a Hitachi U-3210 spectrophotometer.

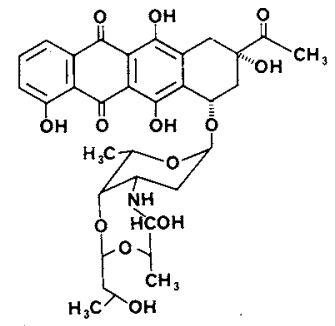

SN-07 chromophore (carbinolamine type)

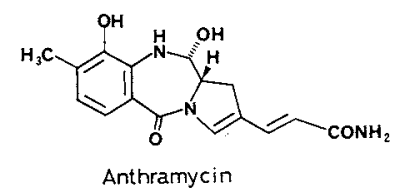

Fig. 1. Structures of SN-07 Chromophore (Carbinolamine Type) and Anthramycin.
Boiling and nuclease digestion. The incubation mixture consisted of $1 \mathrm{mg}$ each of SN-07, (II), or the carminomycin III-DNA complex in $3 \mathrm{ml}$ of the buffer containing $1 / 35 \mathrm{M}$ $\mathrm{CH}_{3} \mathrm{COONa}-\mathrm{CH}_{3} \mathrm{COOH}$, pH 5.3,0.2 $\mathrm{mm} \mathrm{ZnCl}, 10 \mathrm{~mm}$ $\mathrm{MgCl}_{2}$, and $10 \mathrm{mM} \mathrm{CaCl}_{2}$. After denaturation of the DNA complex on boiling at $100^{\circ} \mathrm{C}$ for $5 \mathrm{~min}$, the reaction was carried out at $37^{\circ} \mathrm{C}$ with both an excess of Nuclease P1 $(100 \mu \mathrm{g}$ protein, Yamasa Shoyu Co., Ltd.) and DNase I ( $1 \mathrm{mg}$ protein, Type IV, Sigma Chemical Co.), and $300-\mu \mathrm{I}$ samples were taken and washed with $\mathrm{CHCl}_{3}$ to remove released (I). For measurement of released (I), VIS (505 nm) absorption of the water layer was measured because of the instability of the released (I).

$M I C$ and antibacterial activity. The minimum inhibitory concentrations (MIC) of SN-07 and (II) were measured by the agar dilution method.

To measure the antibacterial activities of various (II) derivatives, we used Staphylococcus aureus IFO 12732 and Salmonella typhimurium TA 1535. They were grown in culture tubes containing $5 \mathrm{ml}$ of bouillon medium (Eiken Chemical Co., Ltd.). Antibacterial activity of $\mathrm{SN}-07$ and various (II) derivatives against them were estimated by the turbidity at $660 \mathrm{~nm}$ with a Spectronic $20 \mathrm{~A}$ (Shimadzu).

Cytotoxicity. In vitro antitumor activities were measured by using cultured cell lines of HeLa, KB, and L1210 leukemia. HeLa and K.B cells were maintained in monolayer culture using Eagle's minimum essential medium (GIBCO) supplemented with $5 \%$ fetal bovine serum (GIBCO). Cells were suspended at a concentration of $1 \times 10^{4}(\mathrm{HeLa})$ and $0.5 \times 10^{4}(\mathrm{~KB})$ cells $/ \mathrm{ml}$, and incubated overnight. They were exposed to a series of 2-fold dilutions of SN-07, (II), or various (II) derivatives. After incubation for 4 days, cells were stained by $0.5 \%$ crystal violet and cell concentrations were measured by an Immuno Reader NJ2000 (Inter Med).

L1210 cells were maintained in suspension culture using RPMI 1640 medium (GIBCO) supplemented with $10 \%$ fetal bovine serum (GIBCO). Cells were suspended at a concentration of $1 \times 10^{4}$ cells $/ \mathrm{ml}$ and incubated overnight. After they were exposed to $\mathrm{SN}-07$ and various (II) derivatives, the cells were counted.

\section{Results}

\section{Absorption spectrum}

As shown in Fig. 2, the absorption spectrum of (II) was identical to that of SN-07. It had two absorption maxima at $259 \mathrm{~nm}$ and $505 \mathrm{~nm}$. (I) showed bathochromic and hypochromic changes in (II) to the same extent as anthracycline and pyrrolo $(1,4)$ benzodiazepine antibiotics. ${ }^{12,18)}$ The bathochromic change was $10 \mathrm{~nm}(495 \mathrm{~nm} \rightarrow 505 \mathrm{~nm})$ and the hypochromic 
change was delta $\max 41 \%$ in $\mathrm{H}_{2} \mathrm{O}$.

\section{Boiling and nuclease digestion}

Boiling and nuclease digestion of SN-07 and (II) led to a release of (I) up to $79 \%$ and $78 \%$, respectively, but carminomycin III was released completely $(100 \%)$ from the carminomycin III-DNA complex only by boiling (Table I).

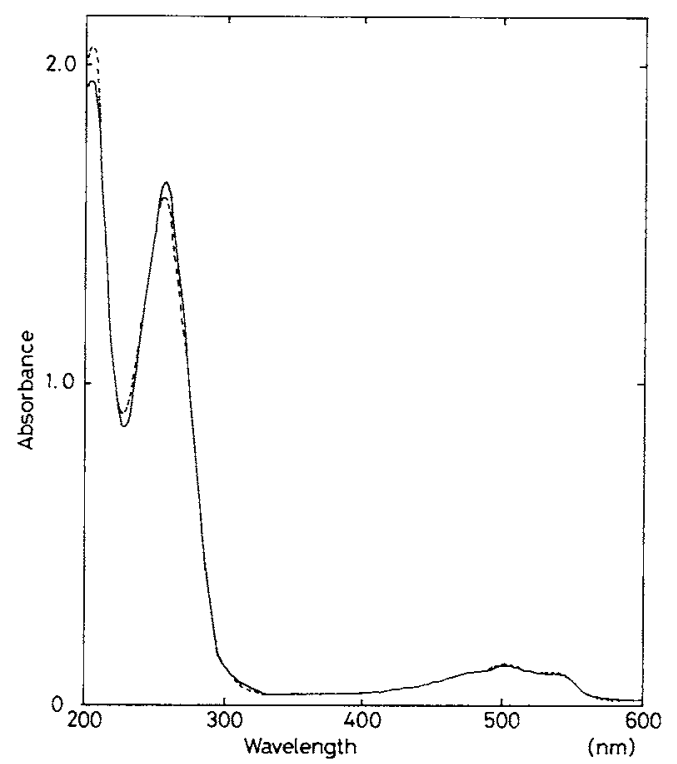

Fig. 2. UV Spectra of SN-07 and Reconstructed SN-07. SN-07 chromophore $(11.1 \mu \mathrm{g})$ was mixed with calf thymus DNA $(88.9 \mu \mathrm{g})$ in $\mathrm{H}_{2} \mathrm{O}$ and UV spectrum was measured at once (within 1 minute). -----, $\mathrm{SN}-07$; - , Reconstructed SN-07.
$M I C$

(II) showed antibacterial activity against both Gram-positive and Gram-negative bacteria, which was similar to that of $\mathrm{SN}-07$, but (II) was the same as or less than that of (I) (Table II).

\section{Cytotoxicity}

(II) showed cytotoxicity against HeLa cells $\left(\mathrm{IC}_{50}=0.02 \mathrm{ng} / \mathrm{ml}\right.$; this value was shown as the (I) equivalent), and was almost the same as SN-07 $\left(\mathrm{IC}_{50}=0.03 \mathrm{ng} / \mathrm{ml}\right)$ (Fig. 3). It also showed cytotoxicity against $\mathrm{KB}$ cells $\left(\mathrm{IC}_{50}=\right.$ $0.006 \mathrm{ng} / \mathrm{ml}$ ) and was almost the same as SN-

Table I. Release of the Free Antibiotic from SN-07, Reconstructed SN-07, AND CARMinomyCiN III-DNA COMPLEX BY BOILING AND NuClEASE Digestion

The quantity of each free antibiotic from DNA complex was measured using a spectrophotometer as described in Materials and Methods.

Release of the free antibiotic $(\%)$

\begin{tabular}{ccc}
$\begin{array}{c}\text { Boiling } \\
\text { for } \\
5 \text { min }\end{array}$ & $\begin{array}{c}\text { Nuclease } \\
\text { digestion } \\
\text { for } 24 \mathrm{hr}\end{array}$ & Total \\
\hline 60 & 19 & 79 \\
35 & 43 & 78 \\
100 & - & 100 \\
& &
\end{tabular}

\begin{tabular}{lrrr}
\hline SN-07 & 60 & 19 & 79 \\
Reconstructed SN-07 (II) & 35 & 43 & 78 \\
Carminomycin III & 100 & - & 100 \\
$\quad$-DNA complex & & & \\
\hline
\end{tabular}

Table II. Antibacterial Activity of SN-07, Reconstructed SN-07, AND SN-07 Chromophore MIC values were measured by agar dilution method. 


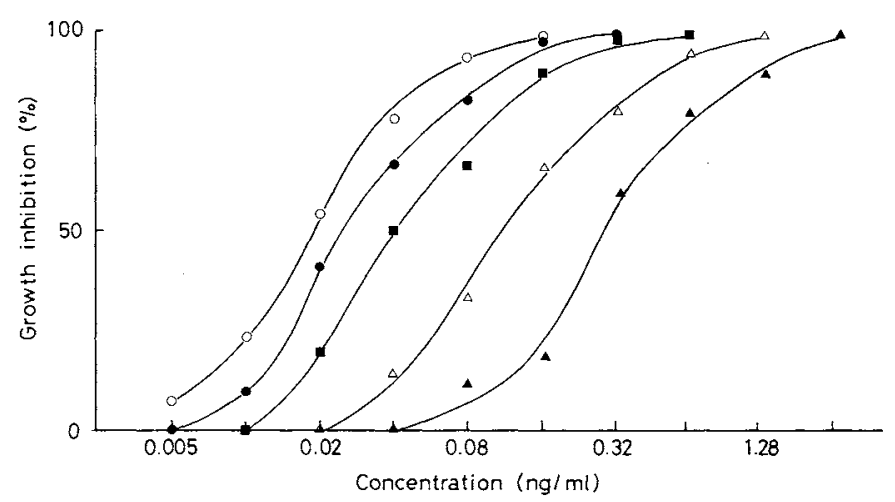

Fig. 3. Cytotoxicity of SN-07 Chromophore, SN-07, Reconstructed SN-07, and various Reconstructed SN0.7 Derivatives to HeLA Cell Culture.

Cytotoxicity was measured using HeLa cell culture as described in Materials and Methods. - $\mathbf{A}-, \mathrm{SN}-07$ chromophore (I); - - , SN-07; - O-, Reconstructed SN-07 (II); $-\triangle-,(\mathrm{I})$-poly $(\mathrm{dI}-\mathrm{dC}) \cdot$ poly $(\mathrm{dI}-\mathrm{dC})$.

Table III. ANTIBACTERIAL ACtivities OF SN-07 CHROMOPHORE, SN-07, AND VARIOUS ReCONSTRUCTED SN-07 DERIVATIVES TO Staphylococcus aureus IFO 12732

Each sample except for the control, including $0.41 \mu \mathrm{g} / \mathrm{ml}$ of $\mathrm{SN}-07$ chromophore, was added to the logarithmic growth phase of Staphylococcus aureus IFO 12732 and the optical density was measured after $24 \mathrm{hr}$ of growth at $37^{\circ} \mathrm{C}$.

\begin{tabular}{|c|c|}
\hline Sample & $\begin{array}{l}\text { Optical } \\
\text { density } \\
(660 \mathrm{~nm})\end{array}$ \\
\hline Control & 1.30 \\
\hline SN-07 & 1.19 \\
\hline$(\mathrm{I})-\operatorname{poly}(\mathrm{dG}-\mathrm{dC}) \cdot \operatorname{poly}(\mathrm{dG}-\mathrm{dC})$ & 1.40 \\
\hline (I)-poly(dG) $\operatorname{poly}(\mathrm{dC})$ & 1.30 \\
\hline (I)-poly $(\mathrm{dA}-\mathrm{dC}) \cdot \operatorname{poly}(\mathrm{dT}-\mathrm{dG})$ & 1.10 \\
\hline SN-07 chromophore (I) & 0.18 \\
\hline (I)-poly (dA-dT) - poly(dA-dT) & 0.19 \\
\hline (I)-poly (dA) - poly (dT) & 0.19 \\
\hline (I)-poly (dI-dC) - poly $(\mathrm{dI}-\mathrm{dC})$ & 0.18 \\
\hline
\end{tabular}

$07\left(\mathrm{IC}_{50}=0.008 \mathrm{ng} / \mathrm{ml}\right)$ (data not shown). The cytotoxicity of (II) and $\mathrm{SN}-07$ against $\mathrm{HeLa}$ cells were about $10 \sim 20$ times stronger than that of (I) under our conditions $\left(\mathrm{IC}_{50}=0.28 \mathrm{ng} / \mathrm{ml}\right)$ (Fig. 3).

The effects of SN-07 and (II) on growth of L1210 cells were also identical (Fig. 4).
Table IV. EFFECTS OF DNA, RNA, AND

BSA UPON THE INHIBITORY ACTION OF SN-07 Chromophore ON GrowTH OF Salmonella typhimurium TA1535

SN-07 chromophore $(1 \mu \mathrm{g} / \mathrm{ml})$ and each carrier (DNA, RNA, or BSA) was added to the logarithmic growth phase of Salmonella typhimurium TA1535 at the same time and the optical density change was measured after $3 \mathrm{hr}$ of growth at $37^{\circ} \mathrm{C}$.

\begin{tabular}{cc}
\hline Sample & $\begin{array}{c}\text { Optical } \\
\text { density } \\
(660 \mathrm{~nm})\end{array}$ \\
\hline 1: Nutrient broth (NB) & 0.32 \\
2: $1+$ DNA $(38 \mu \mathrm{g} / \mathrm{ml})$ & 0.37 \\
3: $1+$ RNA $(38 \mu \mathrm{g} / \mathrm{ml})$ & 0.35 \\
4: $1+$ BSA $(38 \mu \mathrm{g} / \mathrm{ml})$ & 0.38 \\
5: $1+$ SN-07 chromophore $(1 \mu \mathrm{g} / \mathrm{ml})$ & 0.15 \\
6: $5+$ DNA $(38 \mu \mathrm{g} / \mathrm{ml})$ & 0.40 \\
7: $5+$ RNA $(38 \mu \mathrm{g} / \mathrm{ml})$ & 0.18 \\
8: $5+$ BSA $(38 \mu \mathrm{g} / \mathrm{ml})$ & 0.17 \\
9: $5+$ DNA $(19 \mu \mathrm{g} / \mathrm{ml})$ & 0.39 \\
10: $5+$ DNA $(9.5 \mu \mathrm{g} / \mathrm{ml})$ & 0.32 \\
11: $5+$ DNA $(4.8 \mu \mathrm{g} / \mathrm{ml})$ & 0.24 \\
12: $5+$ DNA $(1.9 \mu \mathrm{g} / \mathrm{ml})$ & 0.20 \\
\hline
\end{tabular}

\section{Biological activities of Reconstructed $\mathrm{SN}-07$} derivatives

We prepared (II) using various synthetic polydeoxyribonucleotides to evaluate the role of DNA. The polydeoxyribonucleotides containing guanine in the complex suppressed the activity of (I) and the complex not con- 
(a)

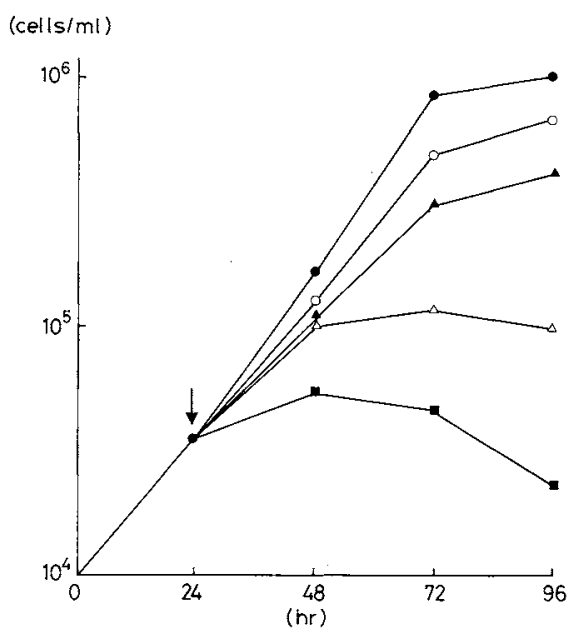

(b)

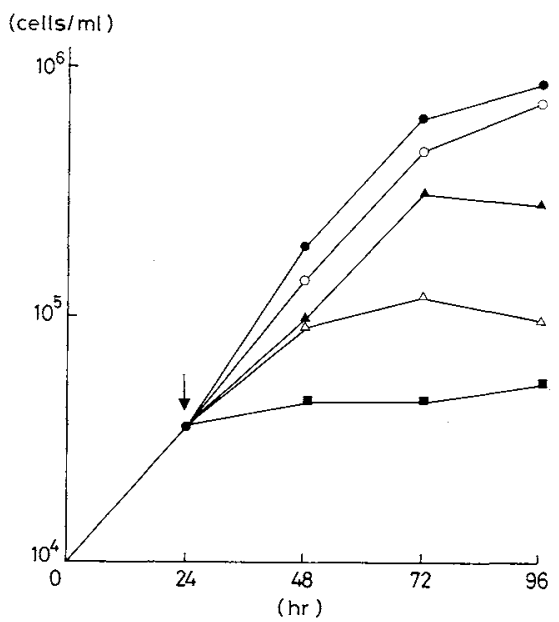

Fig. 4. Effects of $\mathrm{SN}-07$ and Reconstructed $\mathrm{SN}-07$ on Growth of Mouse Leukemia L1210 Cells

Cytotoxicity was measured using mouse leukemia L1210 cell culture as described in Materials and Methods. (a) SN-07, (b) Reconstructed SN-07 (II); - control growth; - $-\mathrm{O}-, 0.1 \mathrm{ng} / \mathrm{ml} ;-\mathbf{\Delta}-, 0.2 \mathrm{ng} / \mathrm{ml}$; $\triangle-, \quad 0.4 \mathrm{ng} / \mathrm{ml} ;-0.8 \mathrm{ng} / \mathrm{ml}$ (the concentration included the weight of DNA).

taining guanine showed almost the same activity as (I) against Staphylococcus aureus IFO 12732. The effects of DNA against the antibacterial activity of (I) were classified into two categories, that is, containing guanine or not (Table III). Similar results were obtained in

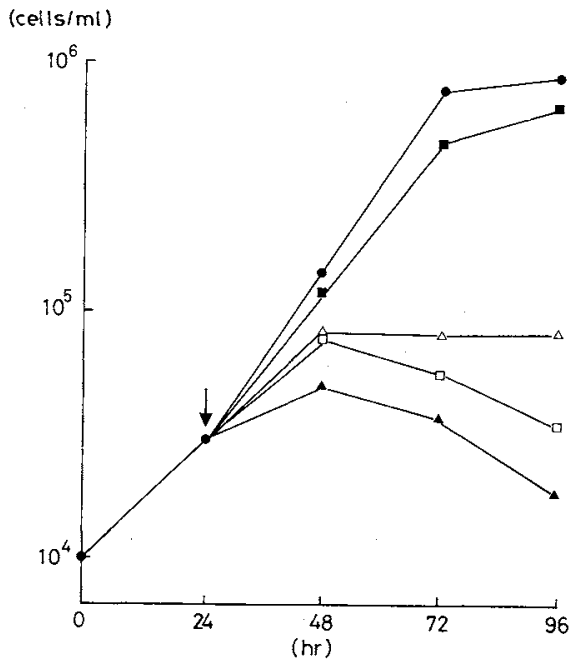

Fig. 5. Effects of various Reconstructed SN-07 Derivatives on Growth of Mouse Leukemia L1210 Cells.

Cytotoxicity was measured using mouse leukemia L1210 cell culture as described in Materials and Methods, and $0.016 \mathrm{ng} / \mathrm{ml}$ of $\mathrm{SN}-07$ chromophore equivalent was added.

- - control growth; - $\mathbf{\Delta - , ~ S N - 0 7 ~ c h r o m o p h o r e ~ ( I ) ; ~}$ - -,$\quad(\mathbf{I})$-poly $(\mathrm{dG}-\mathrm{dC}) \cdot \operatorname{poly}(\mathrm{dG}-\mathrm{dC}) ; \quad-\triangle-, \quad$ (I)poly $(\mathrm{dI}-\mathrm{dC}) \cdot \operatorname{poly}(\mathrm{dI}-\mathrm{dC}) ;-\square-,(\mathbf{I})$-poly $(\mathrm{dA}-\mathrm{dT}) \cdot$ poly(dA-dT).

L1210 leukemia cells (Fig. 5). While all the various (II) derivatives used in above experiments did not suppress the cytotoxicity of (I) against KB and HeLa cells (Fig. 3).

Effects of DNA, RNA, and BSA to the antibacterial activity of $\mathrm{SN}-07$ chromophore

(I) $(1 \mu \mathrm{g} / \mathrm{ml})$ was added at the logarithmic growth phase to Salmonella typhimurium TA 1535 with DNA, RNA, or BSA at the same time. After $3 \mathrm{hr}$ of incubation at $37^{\circ} \mathrm{C}$, the changes of turbidity at $660 \mathrm{~nm}$ were measured. RNA and BSA had no effect on the activity of (I). DNA only suppressed the activity of (I) with increasing dosage (Table IV).

\section{Discussion}

We were interested in the binding mode of (I) to DNA (SN-07 structure) and the role of DNA in SN-07 because (I) had an unique structure. So we characterized the novel macromolecular antitumor antibiotic SN-07 by the 
reconstruction of SN-07 in vitro from (I) and calf thymus DNA. We compared (II) with the native $\mathrm{SN}-07$ in various characteristics such as ultraviolet absorption spectrum, nuclease resistance, and biological activities. All examined characteristics of (II) was almost identical with native $\mathrm{SN}-07$. It was evident that $\mathrm{SN}-07$ consisted of DNA and (I).

We showed (I) had the carbinolamine structure in common with pyrrolo $(1,4)$ benzodiazepine antibiotics (Fig. 1). We speculated that (I) had two DNA binding sites in the structure, one a carminomycinone moiety and the other a carbinolamine (or chemical equivalent). This was supported by the fact that carminomycin III and SN-706 (a (I)-related anthracycline antibiotic that has a carminomycinone, not a carbinolamine) had less activity than (I) ${ }^{8,9)}$ So we analyzed SN-07 and (II) to compare with the anthracycline-DNA and pyrrolo $(1,4)$ benzodiazepine-DNA complexes.

On boiling for $5 \mathrm{~min}$, (I) could be released from neither SN-07 nor (II) completely $(60 \%$ and $35 \%$, respectively). This characteristic resembled that of anthramycin. ${ }^{19)}$ But carminomycin III was released from its DNA complex completely $(100 \%)$. Upon continued nuclease digestion, (I) was released partially from SN07 and (II) (Table I). This characteristic might depend on a labile aminal covalent linkage such as the binding of pyrrolo $(1,4)$ benzodiazepine antibiotics to the 2-amino group of guanine. $^{19)}$

The DNA moiety could stabilize (I) against heat- and nuclease-denaturations (Table I), but DNA containing guanine suppressed the activity of (I) against some bacteria and L1210 cells (Table III, Fig. 5). This showed that one biologically active site (the carbinolamine structure) was masked by DNA. But RNA and BSA did not suppress the activity of (I) (Table IV). Similar results were obtained with tomaymycin. ${ }^{20)}$ From this indirect evidence, we speculated on the structure of $\mathrm{SN}-07$ and the binding mode of (I) to DNA as shown in Fig. 6. This model was supported by our following paper. $^{21)}$
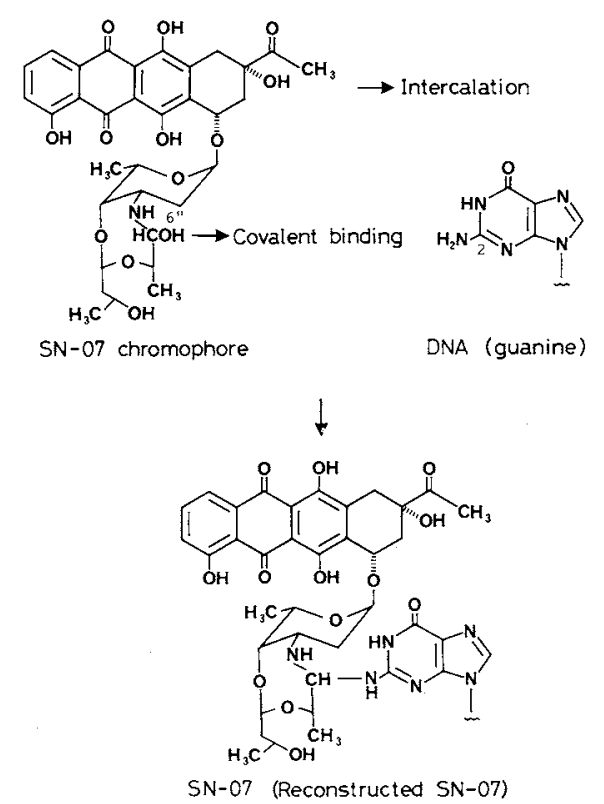

Fig. 6. Hypothetical Structure of $\mathrm{SN}-07$ and Binding Mode of SN-07 Chromophore to DNA.

In contrast to the suppression of activity against some bacteria and L1210 cells, the DNA containing guanine promoted the cytotoxicity of (I) against KB and HeLa cells (Fig. 3). This might be caused by the long incubation of the drug in cell culture and/or the nuclease activity in the culture. It should be gradually released (I) from DNA and attacking the cells continuously, but (I) was unstable in such conditions. We now can take advantage of various (II) derivatives as a suitable prodrug system for (I). In vivo penetration, diffusion of the drug, lysosomal enzyme activity, and so on are different from in vitro experiments. Anthracyclines (adriamycin and daunomycin) and a pyrrolo(1,4)benzodiazepine antibiotic (anthramycin) already are administered as their DNA complexes. ${ }^{19,22,23)}$ But (I) was an unique anthracycline antibiotic in terms of having two types of the binding, intercalation and covalent binding. We could take advantage of this characteristic feature of (I) as the DNA complex by using the DNA containing guanine or not, and we performed in vivo experiments. In our preliminary in vivo experiments, prolongation of the lives of 
P388 leukemic mice differed among (I), (I)poly $(\mathrm{dG}-\mathrm{dC}) \cdot \operatorname{poly}(\mathrm{dG}-\mathrm{dC})$ and (I)-poly(dI$\mathrm{dC}) \cdot \operatorname{poly}(\mathrm{dI}-\mathrm{dC})$ complexes. Details of in vivo experiments will be shown elsewhere.

\section{References}

1) Y. Kikuchi, M. Niwano, N. Yajima, G. Nakamura and N. Miyata, J. Antibiot., 38, 1670 (1985).

2) N. Yajima, N. Miyata, S. Taneya, S. Katayama and K. Nomoto, Proc. Jpn. Cancer Assoc., 44th Annu. Meet., 1985, p. 320.

3) K. Kimura, S. Nakayama, T. Koyama, S. Shimada, N. Kawaguchi, N. Miyata, Y. Takeshita and G. Kawanishi, J. Antibiot, 40, 1353 (1987).

4) M. G. Brazhnikova, V. B. Zbarsky, V. I. Ponomarenko and N. P. Potapova, J. Antibiot., 27, 254 (1974).

5) V. B. Zbarsky, N. P. Potapova, M. G. Brazhnikova, B. V. Rozynov, L. A. Sibeldina and N. F. Sepetov, Antibiotiki, 25, 488 (1980).

6) Y. Matsuzawa, A. Yoshimoto, K. Kouno and T. Oki, J. Antibiot., 34, 774 (1981).

7) Y. Ogawa, H. Sugi, N. Fujikawa and H. Mori, $J$. Antibiot, , 34, 938 (1981).

8) K. Kimura, T. Koyama, S. Nakayama, K. Tamura, N. Miyata and G. Kawanishi, J. Antibiot., 41, 1918 (1988).

9) K. Kimura, S. Nakayama, N. Miyata, Y. Takeshita and G. Kawanishi, J. Antibiot., 41, 411 (1988).

10) T. Uchida, M. Imoto, Y. Takahashi, A. Odagawa, T.
Sawa, K. Tatsuta, H. Naganawa, T. Takeuchi and $H$. Umezawa, J. Antibiot., 41, 404 (1988).

11) K. Kimura, S. Nakayama, N. Miyata and G. Kawanishi, J. Antibiot., 42, 127 (1989).

12) L. H. Hurley, J. Antibiot., 30, 349 (1977).

13) L. H. Hurley and R. L. Petrusek, Nature, 282, 529 (1979).

14) R. L. Petrusek, G. L. Anderson, T. F. Garner, Q. L. Fannin, D. J. Kaplan, S. G. Zimmer and L. H. Hurley, Biochemistry, 20, 1111 (1981).

15) I. N. Maruyama, N. Tanaka, S. Kondo and H. Umezawa, Biochem. Biophys. Res. Commun., 98, 970 (1981).

16) W. Leimgruber, V. Stefanović, F. Schenker, A. Karr and J. Berger, J. Am. Chem. Soc, 87, 5791 (1965).

17) W. Leimgruber, A. D. Batcho and F. Schenker, $J$. Am. Chem. Soc., 87, 5793 (1965).

18) E. Calendi, A. Dimarco, M. Reggiani, B. Scarpinato and L. Valentini, Biochim. Biophys. Acta, 103, 25 (1965).

19) L. H. Hurley, C. S. Allen, J. M. Feola and W. C. Lubawy, Cancer Res., 39, 3134 (1979).

20) G. F. Gause and Yu. V. Dudnik, Prog. Mol. Subcell. Biol., 2, 33 (1971).

21) K. Kimura, S. Nakayama, N. Miyata and G. Kawanishi, Agric. Biol. Chem., 53, 1805 (1989).

22) A. Trouet, D. Deprez-De Campeneere and C. de Duve, Nature New Biology, 239, 110 (1972).

23) C. de. Duve, T. de. Barsy, B. Poole, A. Trouet, P. Tulkens and F. V. Hoof, Biochem. Pharmacol., 23, 2495 (1974). 